\title{
THE COMPARATIVE ANALYSIS OF PRESSURES AND THREATS TO THE NATURA 2000 SITES FOR WILD BIRDS PROTECTION - CASE STUDIES IN WETLANDS IN ROMANIA AND BULGARIA
}

Doina $C I O A C \breve{A} *$

* Ministry of Environment and Climate Changes - Biodiversity Directorate, 12 Libertăţii Boulevard, Sector 5, Bucharest, Romania, doina2004bio@yahoo.com

KEYWORDS: Romania, Bulgaria, Cernica Lake and Forest, Natura 2000, management planning, wetlands.

\section{ABSTRACT}

The Natura 2000 concept and wetlands protection are relatively new for Romania and Bulgaria, because they are former communist countries and, after the 1990s, had too little value placed on nature conservation in favour of infrastructure development and agriculture. The development of the European ecological network Natura 2000 on these territories has come as an obligation for accession of these countries to The European Union on 01.01.2007.

During the period 2006-2009 I made an analysis for the management of protected areas along the Danube Green Corridor, between Romania and Bulgaria, especially for wetlands, similar to the results of the WWF Germany project "Lower Danube - Green Corridor (LDGC): Freshwater protected area management and freshwater restoration in Bulgaria, Romania and trans-boundary conservation along the Lower Danube". To have a complete view of the situation of the protected areas management between Romania and Bulgaria, along the Lower Danube Green Corridor, and the perspectives for the next years, I carried out some evaluation for more than 20 Natura 2000 sites, which are alike in many ways, such as: the object of protection (Sites of Community Importance, SCI, under the Habitats Directive; Special Protection Areas for birds, SPAs, under the Birds Directive; natural protected areas of national importance for these two countries, or other natural and semi natural areas with the potential to be protected), human activities, pressures and threats, and other aspects.

Later, I used these results to make a comparative analysis of the Cernica area (Ilfov County, Romania), to add another argument to include it in the Natura 2000 Network from Romania, as ROSPA0122 Cernica Lake and Forest.

This analysis showed that Cernica faces approximately the same pressures and threats as other protected areas and has almost the same efficiency in management planning as the highest assessed Natura 2000 SPAs, respectively Iezer-Călăraşi in Romania and Srebarna of Bulgaria, which is an argument to establish this area as a Natura 2000 site.

ZUSAMMENFASSUNG: Vergleichende Analyse der Belastungen und Bedrohungen für Natura 2000 Vogelschutzgebiete - Fallstudie in Feuchtgebieten Rumäniens und Bulgariens.

Das Natura 2000-Konzept und der Schutz von Feuchtgebieten ist relativ neu für Rumänien und Bulgarien, da in diesen ehemaligen kommunistischen Ländern auch nach 1990 im Vergleich zu Infrastrukturentwicklung und Landwirtschaft weniger Wert auf Naturschutz gelegt wurde. Die Einrichtung und Entwicklung des europäischen, ökologischen Netzwerks Natura 2000 gehörte jedoch zu den Voraussetzungen und Verpflichtungen im Hinblick auf den Beitritt dieser Länder in die EU zum 01.01.2007. 
Im Zeitraum 2007-2009 hat die Verfasserin eine vergleichende Analyse des Managements von Naturschutzgebieten im „Grünen Korridor Untere Donau“ zwischen Rumänien und Bulgarien vorgenommen und zwar vorwiegend in Feuchtgebieten. Die Studie war Teil der Ergebnisse eines Projektes der Umweltstiftung WWF-Deutschland "Grüner Korridor Untere Donau - Green Corridor (LDGC): Management und Renaturierung von Süßwasser- und Auenschutzgebieten in Bulgarien und Rumänien sowie grenzüberschreitender Naturschutz entlang der unteren Donau“. Um einen umfassenden Eindruck zur Lage der Naturschutzgebiete sowie ihrer Zukunftsperspektive entlang der Donau in Rumänien und Bulgarien zu gewinnen, wurden Evaluierungen für mehr als zwanzig Natura 2000-Gebiete beider Länder vorgenommen. Dabei ging es um Gebiete, die einander in vieler Hinsicht ähnlich waren und zwar um nach der FFH-Richtlinie ausgewiesene Gebiete von Gemeinschaftlicher Bedeutung (SCI), um solche, die nach der Vogelschutzrichtlinie ausgewiesen sind (SPA), um Naturschutzgebiete von nationaler Bedeutung sowie um andere natürliche oder naturnahe, als Naturschutzgebiete auszuweisende Bereiche, um die menschlichen Tätigkeiten in diesen Gebieten, um Belastungen und Bedrohunegn, denen sie ausgesetzt sind und andere wichtige Aspekte.

Die Ergebnisse der Studie und die daraus gewonnenen Erkenntnisse wurden danach für einen Vergleich einiger Natura 2000 Gebiete mit dem Gebiet Cernica (nahe Bukarest), Kreis Ilfov, Rumänien herangezogen, wodurch ein Beitrag für die Aufnahme des Feuchtgebietes unter ROSPA0122 Cernica-See und Cernica-Wald (Lacul şi Pădurea Cernica) in das Netzwerk Natura 2000 geleistet wurde.

Die Analyse hat gezeigt, dass das Cernica-Gebiet etwa den gleichen Belastungen und Bedrohungen ausgesetzt ist, als die anderen zum Vergleich herangezogenen Naturschutzgebiete. Auch hat es fast die gleiche Effizienz in der Managementplanung als die nach der Vogelschutzrichtlinie (SPA) ausgewiesenen und sehr gut bewerteten Natura 2000Gebiete wie Iezer Călăraşi/Rumänien und Srebarna/Bulgarien, was zusätzliche Argumente für die Aufnahme in das Natura 2000-Netzwerk lieferte.

REZUMAT: Natura 2000 este un concept relativ nou pentru România şi Bulgaria, venind ca o obligaţie pentru aderarea acestor ţări la Uniunea Europeană.

În perioada 2007-2009 am realizat o analiză a managementului ariilor protejate din Coridorul Verde al Dunării de Jos, între România şi Bulgaria, în special pentru zonele umede, ca rezultat al proiectului WWF Germania "Lower Danube-Green Corridor (LDGC): Freshwater protected area management and freshwater restoration in Bulgaria, Romania and transboundary conservation along the Lower Danube". Pentru a avea o imagine completă a situaţiei ariilor naturale protejate de-a lungul Dunării, din România şi Bulgaria, precum şi a perspectivei acestora pentru următorii ani, am realizat câteva evaluări pentru peste 20 de situri Natura 2000 din ambele state, care se aseamănă în multe privinţe, cum ar fi: obiectul protecţiei (Situri de Importanţă Comunitară - SCI, în baza Directivei Habitate, Arii de Protecţie Specială Avifaunistică - SPA, în baza Directivei Păsări, arii naturale protejate de importanţă naţională, precum şi alte zone naturale sau seminaturale potenţial a fi incluse în sistemul de arii protejate), activităţile din aceste arii, presiunile şi ameninţările la care sunt supuse, alte aspecte importante.

Ulterior, am folosit rezultatele obţinute pentru a pune în comparaţie câteva situri Natura $2000 \mathrm{cu}$ zona Cernica din judeţul Ilfov (România) şi a contribui la munca de includere a zonei umede ROSPA0122 Lacul şi Pădurea Cernica, în Reţeaua Natura 2000.

Analiza a arătat că Cernica se confruntă aproximativ cu aceleaşi ameninţări ca şi celelalte arii naturale protejate şi are eficiență similară în planificarea managementului faţă de cele mai bine cotate situri Natura 2000 de tip SPA, respectiv Iezer Călăraşi din România şi Srebarna din Bulgaria, constituind astfel un argument pentru constituirea în sit Natura 2000. 


\section{INTRODUCTION}

According to Wetlands Convention, the wetlands are swamps, marshes, bogs, natural or artificial water, permanent or temporary, that is stagnant or flowing water, fresh, brackish or salt water, including stretches of sea water whose depth at low tide does not exceed six meters.

Wetlands are refuges for many species of organisms found only in such optimum places for survival. Such sites are centers for these species spreading when climatic factors are changing. Wetlands are places for breeding, feeding, wintering, etc., for many aquatic and semi-aquatic species. In certain areas tens of thousands of birds (especially ducks, geese, garlic and shore birds) are regularly seen. Some mammals (otter, mink, etc.) exist only in places less disturbed by humans and many species of wild animals survive only in natural wetlands.

Wetlands play an important role in the development of natural processes in ecosystems, but in the same time they have a high economic importance.

Wetlands take some of the flood, spread them on large areas and thus contribute to considerably reducing the destructive power of floods. Wetlands play an important role in stabilizing banks (reducing erosion). They also act as a filter and retain sediments (solid particles of various sizes floating in the water). The importance of the protection and sustainable development of wetlands in Romania resides in the fact that it has acceded to the Convention on Wetlands of International Importance, especially as Waterfowl Habitat, which was signed in Ramsar (Iran) on by February 2, 1971 and ratified by National Law no. 13/1993.

As a condition for joining the European Union on 1 January 2007, the two countries, Romania and Bulgaria were required to prepare a list of Natura 2000 sites within their territories, to expand the European ecological network Natura 2000.

Due to a rich flora and fauna, many of the Natura 2000 sites from the two states were designated in wetlands, mostly along the Danube River.

In the Natura 2000 networks from Romania and Bulgaria were introduced other wetlands types too, like marshes, bogs or natural and semi natural lakes, which host important species of flora and fauna.

\section{MATERIALS AND METHODS}

To obtain the results of the comparative analysis it is important to use a specific questionnaire of my own method for Estimating the Efficiency of Management Planning in Natura 2000 Sites that can be adapted to sites under evaluation. This method was created by myself, in 2007, from the WWF Germany project, and it is innovated from the RAPPAM method (Rapid Assessment and Prioritization for Protected Areas Management), of WWF International (Ervin, 2002).

With this method, I have demonstrated which are the most important pressures and threats for each site and which site needs rapidly intervention for conservation. Also, it can be used for any Natura 2000 site from Europe, whether it has a legal administrator or not. It is simple to apply this method. It is based on a specific questionnaire and much information for the assessed sites.

A range of information is required, such as: legal base; type of the Natura 2000 site or the protected area; the existence of one legal custodian or administrator of the protected area / Natura 2000 site; the existence of the regulation and management plan for each protected area and how were they made; the informations considering the existence of infrastructure for a management guarantee (buildings, transport vehicles and equipments for interventions, access roads to the protected area, access ways for visiting the protected area, the informative panels 
in the proximity of the protected areas, etc.); scientifical information (collecting the information pointed out by other scientifical researchers, observations for the flora and fauna elements on field, including the alien species); the pressures and threats for these natural areas; the information regarding the financial aspects of these natural areas or the future financial possibilities, especially for the Natura 2000 sites; the information regarding the existing ecological reconstruction cases, or to the possibilities of making ecological reconstruction in some areas; the information about the human interventions through hidrotechnical buildings, rivers controls, ponds, pools, lakes for fishing, banks protections, dams etc.; the industrialization and urban expansion information, including transboundary ones; the information regarding the communication level between the stakeholders from these areas and other persons, including the informational transboundary exchanges; the information for the possibility of implementation of a double management into the transboundary region and other information, including maps, pictures, etc.

The specific evaluation questionnaire is divided into nine points (themes), each having a set of relevant questions. The responses to specific questions in the questionnaire are numbered after a certain algorithm and then placed in graphics to have an image of the entire situation. The efficiency of Natura 2000 sites management planning was calculated according to site objectives (item 6), financial resources (item 8) and management planning (item 9), whose sets of questions are found in the specific questionaire. To each answer to the questions is given a score between 0 and 5 , which means: blank $=$ no answer; $0=$ no; $1=$ mostly not; $3=$ mostly yes and $5=$ yes. Depending on how many questions are in each set of the questionnaire, the minimum score can be 0 and the maximum for some sets of questions, may be 40 . For Natura 2000 sites objectives - maximum 20, the financial resources - maximum 15 and for the management planning - maximum 40. The final score obtained on the basis of answers to sets of questions above, will have the cumulative values.

The pressure level is calculated based on the expansion, impact and duration. The threat level is calculated according to the appearance, expansion, impact and duration. The expansion values are: generalized - 4, extensive -3 , isolated -2 and local -1 . The impact is calculated from severe -4 , high -3 , moderate -2 and low -1 . Duration values are: permanent 4 , long term -3 , average -2 and short time -1 . The appearance of threats is calculated with the next scores: possible -1 , somehow possible -2 , very possible -3 , almost sure -1 and constant - 0 . The pressure and threat levels are calculated according to their magnitude and duration. Magnitude is the product of multiplying the expansion and the impact.

The author conducted the study to assess the Natura 2000 sites along the Danube between 2006 and 2009, but the necessary information for comparative analysis with Cernica has been updated so far. To obtain the special Natura 2000 status for Cernica area in 2011, the author conducted an extensive scientific study during 2001 to 2010.

\section{RESULTS AND DISCUSSIONS}

From the nature conservation point of view, in the interest areas are noticed a large variety of habitats (riparian and meadow woods, temporary and permanent wetlands, flooding areas, rivers, lakes and the old branches of the Danube River), and a rich biological diversity, represented by many wild flora and fauna species, protected by national law, by the European Commission Directives (Birds and Habitats Directives) and also by the other International Conventions and Agreements signed by Romania (Ramsar, Berna, Bonn, the Agreement on the Conservation of African-Eurasian Migratory Waterbirds - AEWA, etc.). A high biological diversity exists in the areas with the minimum accessibility for the humans, especially on the neutral islets between Romania and Bulgaria. The wild fauna is rich and diverse, because of 
the aquatic and terrestrial ecosystems diversity. The species inventory of both terrestrial and aquatic habitats from lower Danube reveals an impressive number of species, many of them globally important, including 906 species of terrestrial plants, 502 species of insects, 10 species of amphibians, 8 species of reptiles, 56 species of fish, 160 species of birds, and 37 species of mammals (WWF Romania, 2007). In Cernica Lake and Forest Natura 2000 Site were inventoried many wild species: 141 invertebrates, 5 amphibians, 23 fish, 5 reptiles, 123 birds, 11 mammals and 185 plants (Gogu-Bogdan, 2003; Botnariuc and Tatole, 2005; Cioacă, 2012).

The selected Natura 2000 sites for the comparative analysis are: ROSPA0010 Bistreţ, ROSPA0102 Suhaia Lake and ROSPA0051 Iezer-Călăraşi from Romania and BG0000182 Orsoya Fishpond, BG0002024 Ribarnitsi Mechka and BG0000241 Srebarna from Bulgaria.

These Natura 2000 sites were chosen based on several criteria like: all are wetlands (all Romanian sites and Srebarna from Bulgaria are listed in 2012 as Ramsar Sites), all are protected for wild birds as SPA's, according to the Birds Directive of the European Union, all sites are IBA's (Important Birds Areas), according to Bird Life International criteria, in all sites run fishing and hunting activities and all are close to the inhabited areas.

Those Natura 2000 sites were designated for the wild birds' protection and all the pressures and threats were assessed and the proposal motivation of these sites recorded. These pressures and threats are: poaching, including the fishing out of the rules established by law; hunting in the breeding period or in the nests places of the endangered species; destruction of the nests or of the youngest birds; disturbing the wild birds during the nesting period, in the singulars cases or in their colonies; the draining of wetlands; the industrialization and urban expansion in the existent natural assets' detriment; burning reed and the shore vegetation; uncontrolled waste disposal of, with any type of waste, including from the agriculture; using pesticides in agriculture and uncontrolled storing of these, especially nearby the water banks; uncontrolled tourism; forestry activities in nesting areas of birds; uncontrolled reproduction of alien species and the list can go on. Moreover beside of these pressures and threats, can be other, at the national level, which were taken in the estimation of the management planning efficiency for the Natura 2000 sites, for example: not all the stakeholders from these areas are aware of the importance of these Natura 2000 sites; the limits of these sites were not clearly established on the field in both countries, the present or the future methods for financing these Natura 2000 sites have not been established yet; the poverty and low level of mentality of the population from these areas, in terms of nature conservation.

To compare these sites I used four commonly found indicators: poaching, burning reed and the shore vegetation, the uncontrolled tourism and the continue urbanization.

The chart of the general pressures and threats levels (Fig. 1) showed a somehow balanced situation between these Natura 2000 sites. The charts for each indicator are listed below (Figs. 2-5).

The maximum general level of the pressures recorded at Cernica, with 41 , can be explained by the fact that it was not yet included in the Natura 2000 network when I made the comparison. The highest general level of the threats is in Suhaia, which is explained by the fact that in this area a conflict between those who are concerned about nature conservation and the fisheries' administrator still exists. The areas least subject to pressures and threats are found in Iezer-Călăraşi and Srebarna. 


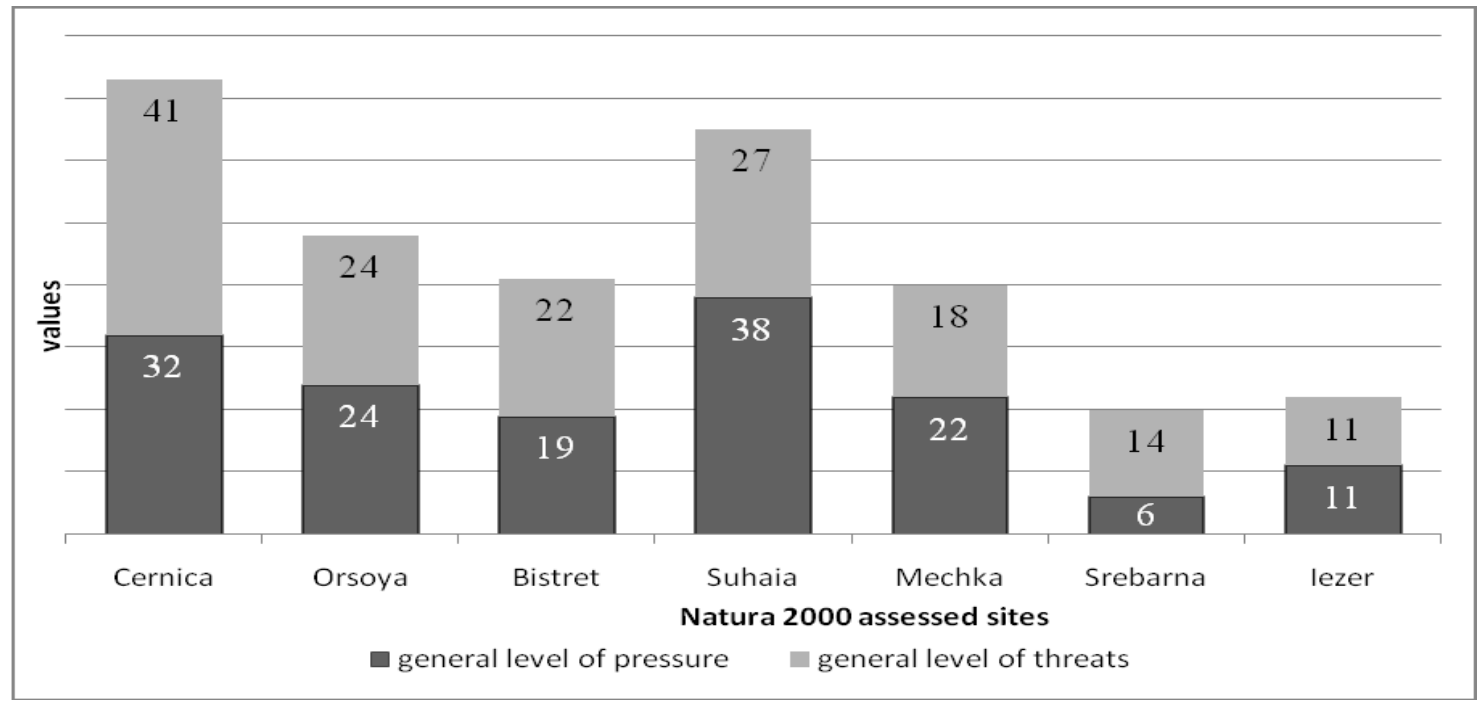

Figure 1. The general levels of pressures and threats.

Burning reeds and vegetation around the water (Fig. 2), especially in the spring when wild birds are nesting, has become lately a more commonly practice used by various dealers of fish ponds, including those under Natura 2000 SPA's.

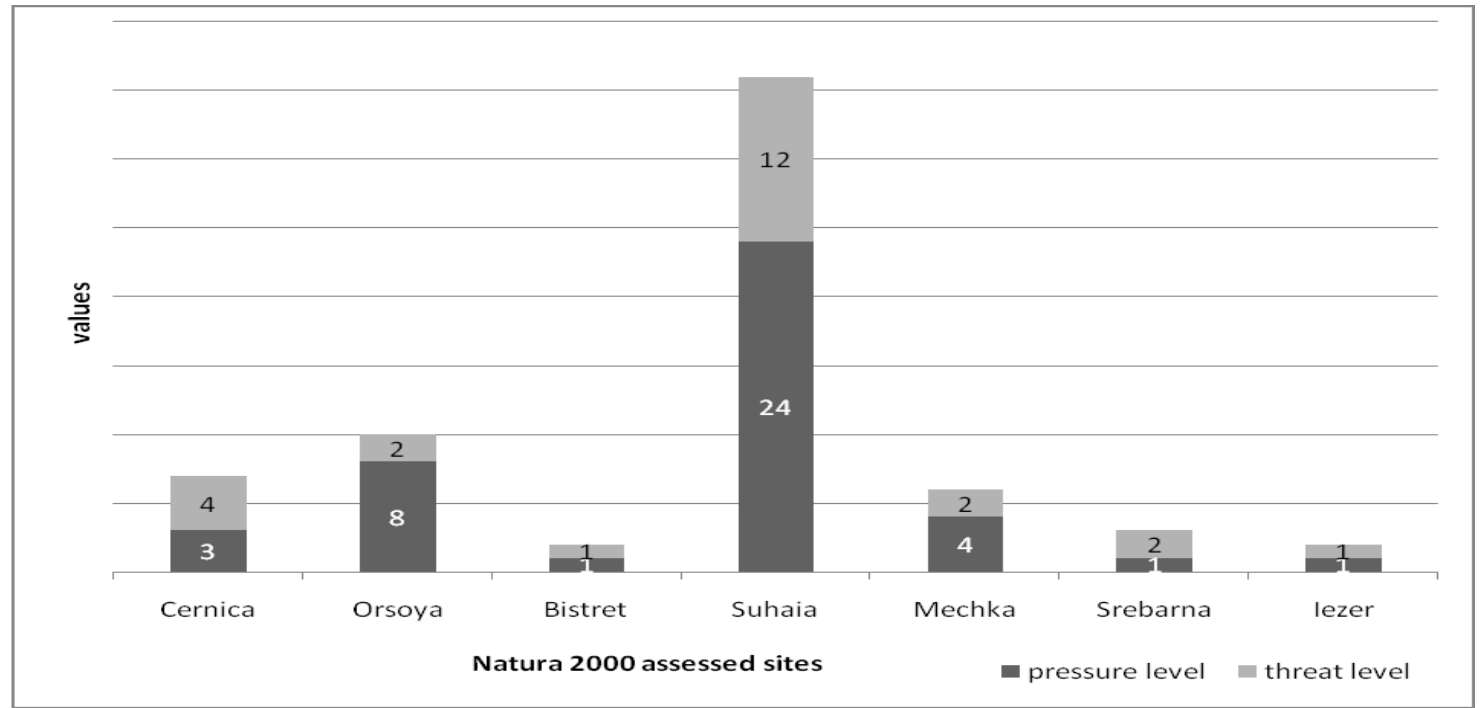

Figure 2. The burning reed and the shore vegetation level.

The highest pressure - 24 is recorded in Suhaia, while the threat is halved - 12, due to the more active involvement of various researchers in order to maintain the natural values of this site. The pressure - 3 and threat - 4 levels of this indicator on the site Cernica comes rather from some traditional practices, less nature friendly, used by locals.

The lowest value - 1, insignificant, is recorded at Bistreţ, Iezer-Călăraşi and Srebarna, explained by the occurrence of accidental burning reed in these areas.

For poaching indicator, both types were considered, from fishing and hunting (Fig. 3). 


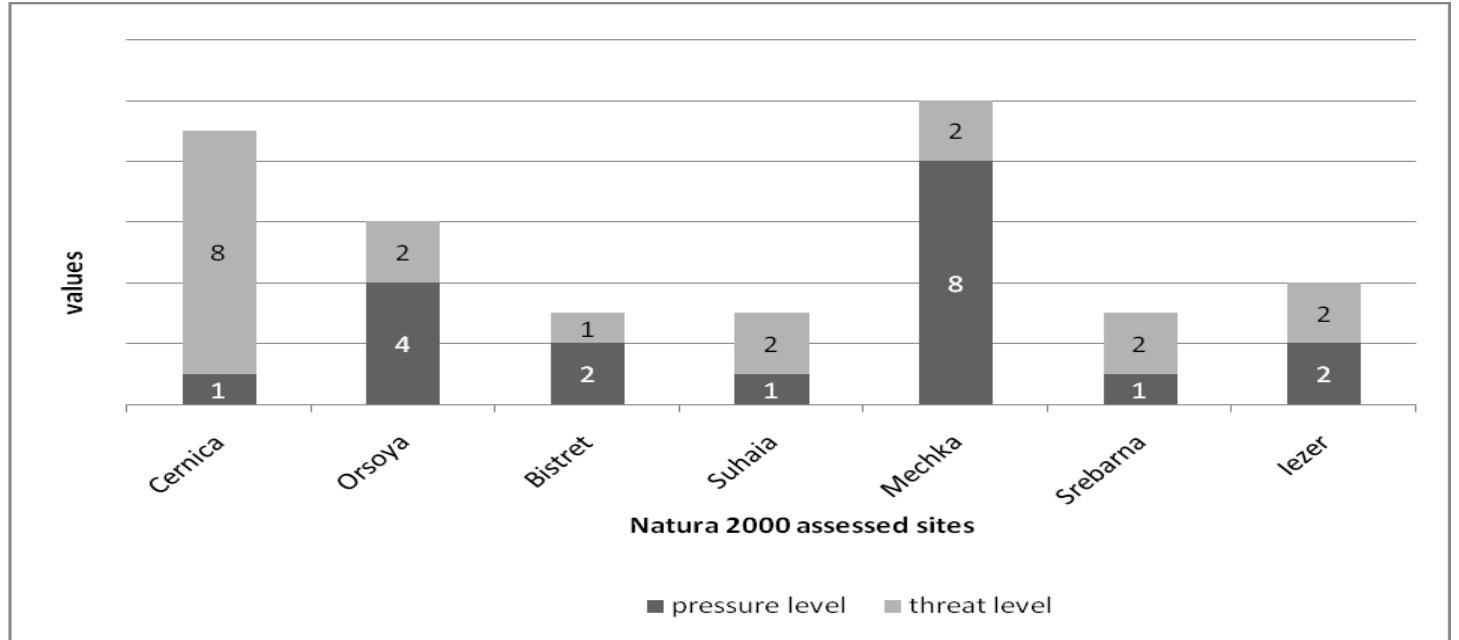

Figure 3. The poaching level.

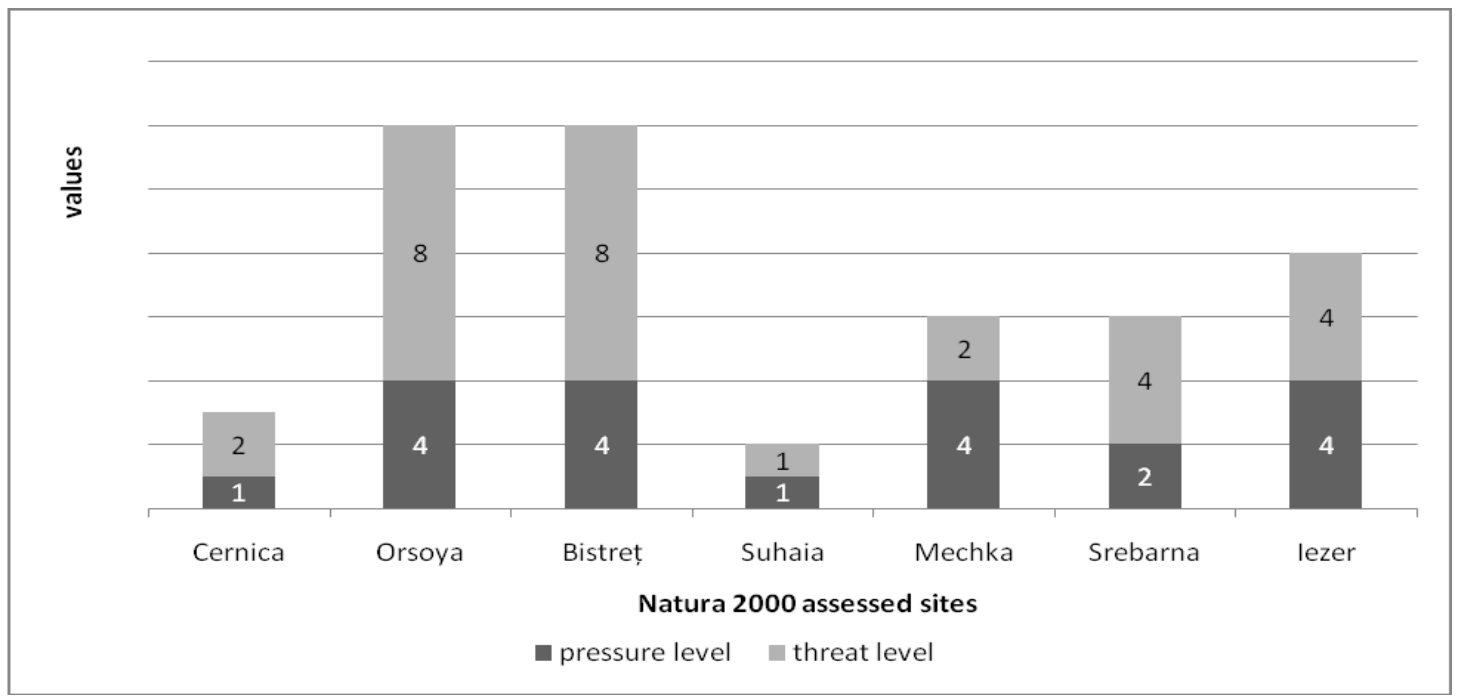

Figure 4. The uncontrolled tourism.

The highest value for this threat is recorded at Cernica - 8, while for pressure Mechka 8 is the highest. The lowest value for pressure - 1 is recorded at Suhaia, Srebarna and Cernica sites and also the lowest threat -1 is in the Bistreț. The tourism is preferably made in natural areas, causing extensive damage: garbage disposal, fire, disturbance of species, etc. The chart of the uncontrolled tourism showed some similarities between the evaluated Natura 2000 sites (Fig. 4). The maximum pressure level is recorded in Bistreţ and Iezer-Călăraşi (RO) and Orsoya and Srebarna (BG). The lowest pressure level is recorded at Cernica and Suhaia, because of the fact that in Cernica are several locations for organized leisure and in Suhaia the access of weekend tourists is restricted by the administrator of the fisheries.

The desire for urban expansion in natural areas comes from the fact that the population has increased over time, but also due to the need for peace and relaxation, resulting from intensive activities. The highest level of pressure and threat for urbanization is recorded at Cernica and the lowest, in case of threat only, at Iezer-Călăraşi (Fig. 5). 


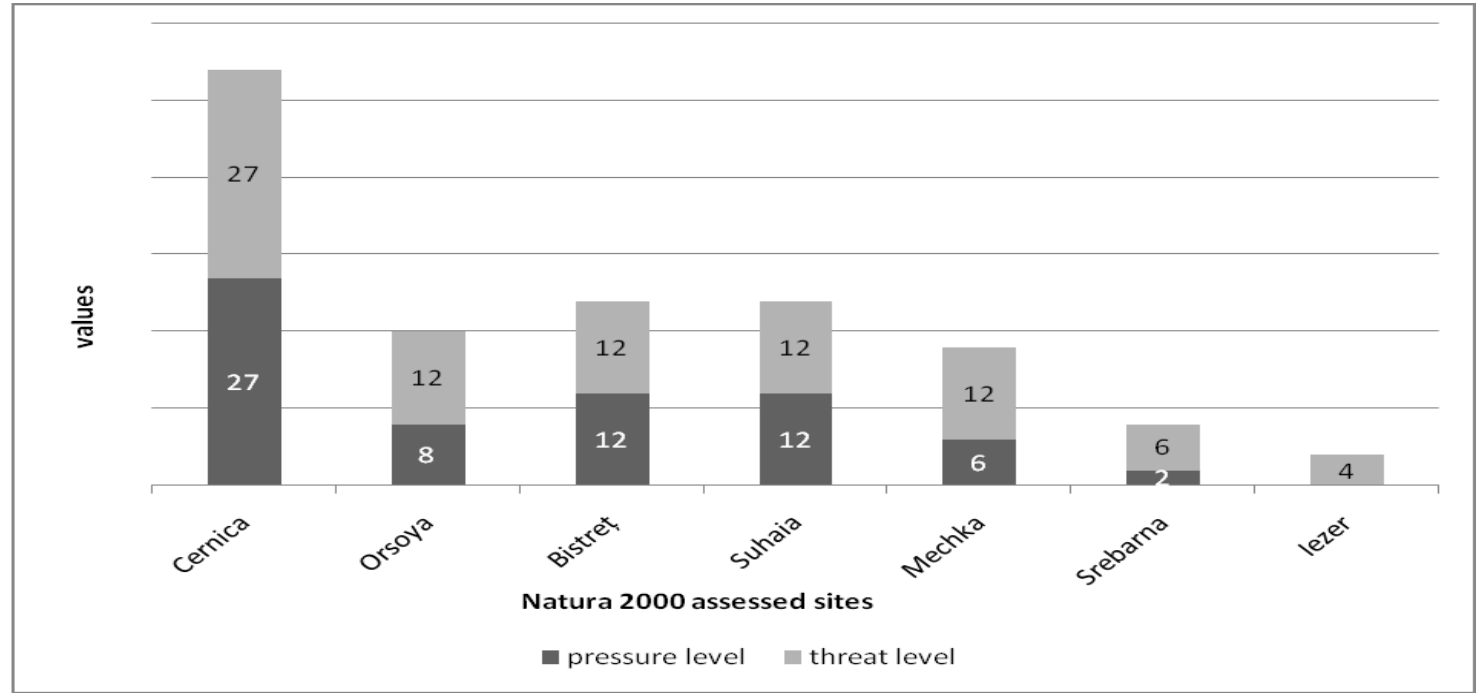

Figure 5: The urbanization level.

Once a Natura 2000 site is designated, the question is if their administrators are able to maintain a favorable conservation status of the protected natural elements. To have success in management it is necessary to establish clear objectives for the protection of the site, finding the necessary funds to support and organize a long-term action plan. The chart for management planning efficiency in the assessed Natura 2000 sites showed the rated sites (Fig. 6).

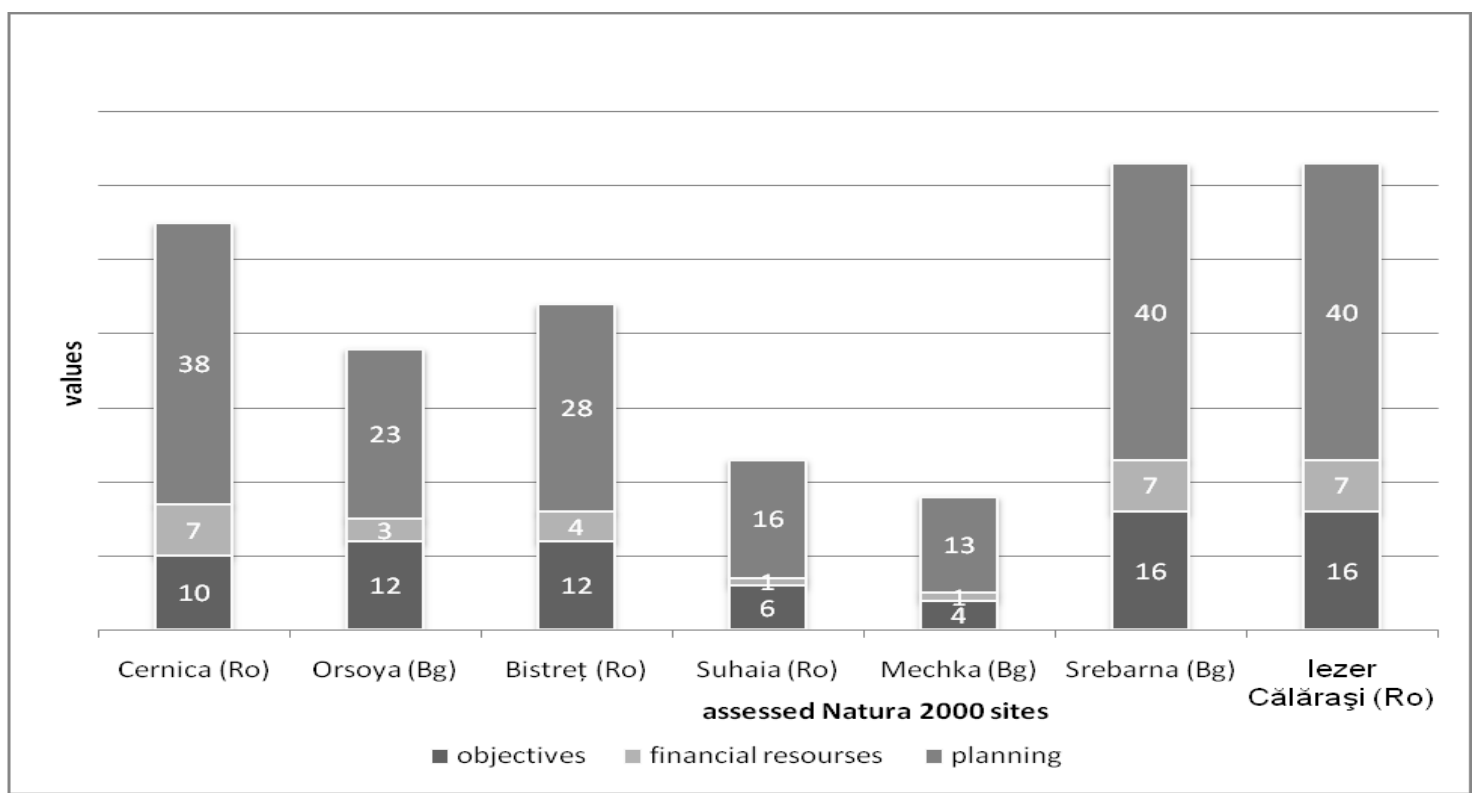

Figure 6: The management planning efficiency.

By comparing the management planning efficiency between Cernica and 6 other Natura 2000 sites, the results shows that Srebarna and Iezer-Călăraşi have the best efficiency in the management of these protected areas. Cernica has values close to these sites, which means that it is able to maintain a good state of preservation, after setting up the Natura 2000 site. The poorest efficiency in Natura 2000 site management planning appears to be at Mechka, followed by Suhaia. 


\section{CONCLUSIONS}

In present, in Cernica area there are two Natura 2000 Sites, ROSPA0122 Cernica Lake and Forest, in 2006, revised and accepted in 2010 and it was published in The Official Journal of Romania no. 715 from 11.10.2011 by Government Decision no. 971/2011.

The other Natura 2000 Site, ROSCI0308 Cernica Lake and Forest, proposed in 2006, was accepted by Order no. 2387/2011 of the Minister of Environment and Forests. 


\section{REFERENCES}

1. Botnariuc N. and Tatole V., 2005 - Cartea Roşie a vertebratelor din România (Red Book of Vertebrates from Romania), Academia Română - Muzeul Naţional de Istorie Naturală "Grigore Antipa”, Bucharest, 260, ISBN 973-0-03943-7

2. Bruun B., Delin H. and Svensson L., 1999 - Hamlyn Guide: Păsările din România şi Europa, determinator ilustrat, Octopus Publishing Group Ltd, Londra, 54. (in Romanian)

3. Cioacă D., 2007 - Raport final privind evaluarea situaţiei ariilor naturale protejate şi a zonelor de reconstrucţie ecologică din lungul Dunării în România, 94, Raport intern din cadrul proiectului "The Lower Danube - Green Corridor: Freshwater protected areas management and freshwater restoration in Bulgaria, Romania and transboundary conservation along the Lower Danube" al WWF Germania. (in Romanian)

4. Cioacă D., 2008 - Final Report: Integration of results of assessment in Romania and Bulgaria on the conservation and ecological restoration practices in protected area along The Lower Danube Green Corridor, 47, Raport intern din cadrul proiectului "The Lower Danube - Green Corridor: Freshwater protected areas management and freshwater restoration in Bulgaria, Romania and transboundary conservation along the Lower Danube" WWF Germania.

5. Cioacă D., 2012 - Animal species and habitats protected in "Natura 2000" sites Cernica Lake and Forest (Ilfov County, Romania), Romanian Journal of Biology - Zoology, 57(1), 29-37).

6. Ervin J., 2002 - Rapid Assessment and Prioritization of Protected Area Management (RAPPAM) Methodology, WWF International.

7. Kostadinova I. and Gramatikov M. (eds), 2007 - Important Bird Areas in Bulgaria and Natura 2000i, BSPB Conservation Series 11. Sofia: Bulgarian Society for the Protection of Birds. (in Bulgarian and English).

8. Papp T. and Fântână C. (eds), 2008 - Ariile de Importanţă Avifaunistică din România. TîrguMureş: Societatea Ornitologică Română, Bucureşti şi Asociaţia pentru Protecţia Păsărilor şi a Naturii 'Grupul Milvus'. (in Romanian)

9. $* * *$ Council Directive 79/409/EEC of 2 April 1979 on the conservation of wild birds (Directiva Consiliului Europei 79/409/EEC privind conservarea păsărilor sălbatice, adoptată la 2 aprilie 1979) cu modificările ulterioare.

10. *** Council Directive 92/43/EEC of 21 May 1992 on the conservation of natural habitats and of wild fauna and flora (Directiva Consiliului Europei 92/43/EEC referitoare la conservarea habitatelor naturale, a faunei şi florei sălbatice, adoptată la 21 mai 1992).

11. *** Legea nr. 13 din 11 martie 1993 pentru aderarea României la Convenţia privind conservarea vieţii sălbatice şi a habitatelor naturale din Europa, adoptată la Berna la 19 septembrie 1979.

12. *** Legea nr. 13 din 8 ianuarie 1998 pentru aderarea României la Convenţia privind conservarea speciilor migratoare de animale sălbatice, adoptată la Bonn la 23 iunie 1979

13. *** Legea nr. 5 din 25 ianuarie 1991 pentru aderarea României la Convenţia asupra zonelor umede, de importanţă internaţională, în special ca habitat al păsărilor acvatice (Convenţia Ramsar)

14. $* * *$ http://www.ramsar.org/pdf/sitelist_order.pdf

15. *** Bulgarian Society for the Protection of Birds, 2007 - Important Birds Areas in Bulgaria and Natura 2000, Conservation Series - Book 1, Sofia.

16. *** Association of Parks in Bulgaria, 2007 - WWF Germany Project, Overview of the Lower Danube Green Corridor Declaration Implementation in Bulgaria.

17. *** Gogu-Bogdan M., 2003 - Listă cu specii de păsări prezente în zona Cernica, Ilfov.

18. $* * *$ http://bd.eionet.europa.eu/activities/Natura_2000/reference_portal

19. $* * * \mathrm{http}: / /$ ec.europa.eu/environment/nature/natura2000/.Natura 2000 network 